\title{
Contrasting effects of progesterone on fertility of dairy and beef cows ${ }^{1,2}$
}

\author{
J. S. Stevenson ${ }^{* 3}$ and G. C. Lamb† \\ *Department of Animal Sciences and Industry, Kansas State University, Manhattan 66506-0201 \\ †Department of Animal Sciences, North Florida Research and Education Center, University of Florida, Marianna 32446-7906
}

\section{ABSTRACT}

The role of progesterone in maintaining pregnancy is well known in the bovine. Subtle differences exist between dairy and beef cows because of differing concentrations of progesterone during recrudescence of postpartum estrous cycles, rate of follicular growth and maturation, proportions of 2- and 3-follicular wave cycles, and other effects on pregnancy outcomes per artificial insemination $(\mathrm{P} / \mathrm{AI})$. Because proportions of anovulatory cows before the onset of the artificial insemination (AI) period are greater and more variable in beef (usually ranging from 30 to $70 \%$ ) than dairy (25\%) cows, AI programs were developed to accommodate anovulatory and cycling beef cows enrolled therein. Incorporating a progestin as part of an AI program in beef cows improved P/AI by reducing the proportion of cows having premature luteal regression and short post-AI luteal phases. In both genotypes, prolonged dominant follicle growth in a reduced progesterone milieu resulted in increased (1) LH pulses, (2) preovulatory follicle diameter, and (3) concentrations of estradiol and a subsequently larger corpora lutea (CL). In contrast, the progesterone milieu during growth of the ovulatory follicle in an ovulation control program does not seem to affect subsequent $\mathrm{P} / \mathrm{AI}$ in beef cows, whereas in dairy cows follicle development in an elevated compared with a low progesterone environment increases P/AI. Progesterone status in beef cows at the onset of ovulation synchronization is not related to $\mathrm{P} /$ $\mathrm{AI}$ in multiparous cows, whereas $\mathrm{P} / \mathrm{AI}$ was suppressed in primiparous cows that began a timed AI program in a low-progesterone environment. In timed AI programs, elevated concentrations of progesterone just before $\mathrm{PGF}_{2 \alpha}$ and reduced concentrations at $\mathrm{AI}$ are critical to

Received July 17, 2015.

Accepted December 26, 2015.

${ }^{1}$ Contribution number 16-015-j from the Kansas Agricultural Experiment Station, Manhattan 66506.

${ }^{2}$ Presented as part of the Progesterone as an Endocrine Regulator Symposium at the ADSA-ASAS Joint Annual Meeting, Orlando, Florida, July 2015.

${ }^{3}$ Corresponding author: jss@k-state.edu maximizing subsequent $\mathrm{P} / \mathrm{AI}$ in dairy cows, but seemingly much less important in beef cows. By inducing ancillary CL and increasing concentrations of progesterone, human chorionic gonadotropin may increase P/ AI when administered to beef cows $7 \mathrm{~d}$ after $\mathrm{AI}$ or at embryo transfer, and its success seems to depend on induction of ancillary CL, whereas in dairy cows increased fertility was detected in cows with multiple CL, human chorionic gonadotropin-enhanced progesterone from original CL, or both. Pregnancy losses after AI are less frequent in beef cows and are not associated with pre-AI progesterone or cycling status, whereas losses in dairy cows are inversely related to progesterone and adversely affected in anovular dairy cows. Genotype and nutritional management likely influence several physiological differences including circulating concentrations of progesterone and responses to supplemental progesterone.

Key words: beef cows, dairy cows, progesterone, fertility

\section{INTRODUCTION}

Factors that influence establishment and retention of pregnancy were identified in an earlier review (Inskeep, 2004). These include (1) preovulatory effects on the follicle and oocyte, (2) early postovulatory uterine and luteal function, (3) hormonal concentrations associated with conceptus and endometrial function during maternal recognition of pregnancy, and (4) less wellunderstood factors during the peri-attachment period. The present report will focus on differences that may exist between Bos taurus beef and dairy cattle with respect to the effects of progesterone in its role as a facilitator to establishing and maintaining pregnancy.

One factor that limits conception is the proportion of cows remaining anestrous or anovulatory at the beginning of the breeding period in suckled and milked cows (Crowe et al., 2014). Factors influencing the incidence of anestrus have been reviewed (Stevenson et al., 1997; Yavas and Walton, 2000; Diskin et al., 2003; Crowe et al., 2014). Traditional differences in management of beef and dairy cows partly contribute to the vary- 
ing recrudescence of postpartum ovarian activity with suckled beef cattle having more prolonged periods of anovulation than dairy cattle (Crowe et al., 2014), despite the fact that regular continuous follicular waves occur every 7 to $10 \mathrm{~d}$ beginning 5 to $10 \mathrm{~d}$ after calving in beef (Stagg et al., 1998) and dairy cows (Lucy et al., 1992). The most common type of anovular lactating dairy cow (60\% of anovular dairy cows) had follicles larger than ovulatory size but smaller than the classically defined cystic follicle (Wiltbank et al., 2011). In contrast, before first ovulation in suckled cows, recurrent periods of growth and regression of dominant follicles occur, but these dominant follicles fail to ovulate and consequently undergo atresia (Murphy et al., 1990) because of a lack of appropriate LH pulse frequency (Crowe et al., 2014). Thus, although suckling increased the interval to first ovulation relative to the intervals reported for dairy cows (Fonseca et al., 1983), it did not delay resumption of follicular growth or development of dominant follicles in suckled beef cows (Murphy et al., 1990).

The nature of the first postpartum ovulation is silent in more than $70 \%$ of beef and dairy cows and is more prolonged in beef cattle because of suckling-induced inhibition of LH pulse frequency (Williams, 1990), with the postpartum interval to first ovulation ranging from 25 to $45 \mathrm{~d}$ in dairy and 30 to $130 \mathrm{~d}$ in beef cattle (Crowe et al., 2014). Direct comparisons of Angus, Simmental, and Holstein cows milked twice daily and fed the same diet revealed that Angus cows $(36 \pm 4$ d) had longer intervals to first postpartum ovulation than Holstein $(20 \pm 3 \mathrm{~d})$ and Simmental cows $(22 \pm 4 \mathrm{~d})$, and at 30 $\mathrm{d}$ after calving, 50,88 , and $92 \%$ of the cows had initiated ovarian cyclicity in the Angus, Simmental, and Holstein breeds, respectively (Masilo et al., 1992). As expected, Holsteins produced more milk (unadjusted or $3.5 \%$ FCM) than Angus or Simmental cows during the first 30 DIM.

Proportions of anovulatory cows at the onset of the AI period are greater and more variable in beef (30 to 70\%; Lamb et al., 2010) than dairy (5 to 41\%; Bisinotto et al., 2014) cows. Exposure to progesterone is a prerequisite to first postpartum behavioral estrus in a large portion of beef cows (Lamb et al., 2010) and dairy cows (Crowe et al., 2014). Although duration and intensity of estrus is compromised in superior milk-producing dairy cows (Lopez et al., 2004), interval from onset of estrus to ovulation seems to be similar in beef $(31 \mathrm{~h}$; White et al., 2002) and dairy (28 h; Walker et al., 1996) cows.

Although most US dairy operations are not seasonal as beef cow-calf operations, many worldwide grazing dairy operations are managed with seasonal breeding patterns as beef cattle. Dairy cows generally are fed ad libitum diets calculated to meet maintenance, growth, and milk production requirements or nutritionally supplemented during part of the year in seasonally managed operations. In contrast, beef cows are generally managed to graze native range with some nutrient supplementation depending on the time of their calving and breeding seasons. Therefore, nutritional management of cattle is likely to influence several physiological differences in cattle. Several of these differences may be directly or indirectly influenced by progesterone and luteal function, because circulating concentrations of progesterone are reflective of their biosynthesis by the corpus luteum (CL) and rate of metabolism primarily by the liver (Wiltbank et al., 2014).

Our objective was to contrast the differences in the role progesterone plays in fertility of Bos taurus beef and dairy cattle. Several excellent reviews examining some of the physiological and practical effects of progesterone on reproduction in dairy cattle are available (Bisinotto et al., 2015b; Wiltbank and Pursley, 2014; Wiltbank et al., 2014), which go beyond the scope of this report. A paucity of information exists, however, including reviews of the literature, elucidating the role of progesterone on pregnancy outcomes in beef cattle. Two recent reports (Lamb et al., 2010; Stevenson et al., 2015) provided some information regarding prebreeding progesterone milieu or supplementation and its effects on pregnancy outcomes in beef cattle.

\section{PREOVULATORY INFLUENCES OF PROGESTERONE}

\section{Ovarian Follicular Waves}

Greater DMI in dairy cows of superior milk yield alters splanchnic tissue metabolism and increases catabolism of ovarian steroids, including estradiol and progesterone (Wiltbank et al., 2006). Lactating dairy cows have lesser progesterone concentrations during the estrous cycle than cycling dairy heifers, and concentrations of progesterone are inversely related to CL size (Sartori et al., 2004; Wolfenson et al., 2004). These reduced concentrations of progesterone facilitate a subtle increase in LH pulse frequency and generally prolong the growth phase of dominant follicles compared with that of heifers. Number of follicular waves and rate of turnover of dominant follicles are directly related to the duration of follicle dominance, and cattle with shorter durations of dominance reportedly have greater pregnancy per AI (P/AI; Austin et al., 1999; Santos et al. 2010). Because grazing beef cattle have less DMI compared with dairy cows, nutritional influences, by altering metabolic clearance rate of progesterone and estradiol, likely affect follicle dominance, the number of 
follicle waves per cycle, and indirectly affect P/AI. One might expect, therefore, that circulating concentrations of progesterone and estradiol in suckled beef cattle may resemble those of heifers and may be greater than those detected in lactating dairy cows.

Ginther et al. (1996) reviewed the (1) process of selection of the dominant follicle and increased secretion of FSH, (2) roles of dominance loss by the largest follicle, and (3) acquisition of dependency of LH by the putative dominant follicle. Indirect effects of greater progesterone concentration in beef than dairy cows is supported by shorter dominance of dominant follicles in studies of ovarian follicular waves during the estrous cycle. Number of ovarian follicular waves vary with nutrition in beef heifers (Murphy et al., 1991) or with body condition in dairy cows (Burke et al., 1998), but these are somewhat confounded with management of the herd. Two-follicle waves per estrous cycle are more common than 3 waves in both beef (86.4 vs. $13.6 \%$; Ahmad et al., 1997) and dairy cows (72.4 vs. $27.6 \%$, Townson et al., 2002; 74.7 vs. $25.3 \%$, Bleach et al., 2004), respectively. Furthermore, 2 studies provided evidence that $\mathrm{P} / \mathrm{AI}$ may differ between 2- and 3-wave beef (82 vs. 100\%; Ahmad et al., 1997) and dairy cows (63 vs. 81\%; Townson et al., 2002), respectively. Therefore, it was suggested that follicles that have a longer growth phase in an elevated progesterone environment (analogous to a 2-wave cycle) may produce an aged oocyte (Townson et al., 2002). Fertility did not seem to differ, however, in experimentally induced short or long progesterone-exposed dominant follicle growth, simulating 2 versus 3 waves in beef cows and heifers (53.2 vs. $58.1 \%$; Dias et al., 2012) or in spontaneous 2 versus 3 waves in dairy cows (55.1 vs. $62.9 \%$; Bleach et al., 2004), respectively.

Dairy cows with experimentally induced persistent follicles resulted in larger ovulatory follicles and greater estradiol concentrations than comparable growing follicles, but the resulting CL failed to produce more progesterone (Cooperative Regional Research Project, 1996). In contrast, in beef cows and heifers treated with small doses of progesterone to produce larger persistent follicles, greater concentrations of progesterone were detected on d 6 after estrus (Wehrman et al., 1993). Furthermore, a low progesterone environment during growth of the ovulatory follicle increased the preovulatory follicle size and subsequent CL size and function, and compensated for the effect of a short proestrus on pregnancy rates in beef cows and heifers (Dadarwal et al., 2013). Further experiments in beef cattle designed to create either elevated or reduced concentrations of progesterone during ovulatory follicle growth and maturation failed to enhance timed AI P/AI (Abreu et al., 2014a,b).
In contrast, induction of ovulation of the dominant follicle of the first follicular wave (in which most of the growth phase occurs in a subluteal phase milieu) in dairy cows resulted in reduced fertility compared with a second-wave dominant follicle (Bisinotto et al., 2010; Rivera et al., 2011; Denicol et al., 2012). Furthermore, exogenous maintenance of greater progesterone concentrations during growth of the first-wave dominant follicle improved fertility in dairy cows (Rivera et al., 2011; Denicol et al., 2012). In contrast, when concentrations of progesterone were maintained between 1 and $2 \mathrm{ng} / \mathrm{mL}$ during development of the ovulatory follicle, subsequent fertilization risk and early embryo development up to d 6 after AI were not compromised, suggesting that reduced concentrations of progesterone that disrupt pregnancy in dairy cattle are likely related to embryonic effects observed after d 6 or to changes in periovulatory concentrations of hormones that affect subsequent uterine function (Cerri et al., 2011b). This idea is substantiated by the fact that a marginal progesterone milieu during ovulatory follicle development in dairy cows resulted in reduced $\mathrm{P} / \mathrm{AI}$, greater pregnancy loss, changes in the responsiveness of the endometrium to oxytocin and more short estrous cycles (Cerri et al., 2011a).

The aforementioned dairy studies, compared with the cited study in beef cattle (Dadarwal et al., 2013), were slightly different, with a longer growing phase of the ovulatory follicle (by at least $2 \mathrm{~d}$ ) and a differing pattern of progesterone exposure. In the beef cattle study, progesterone concentrations were subluteal from follicle recruitment to removal of the progesterone insert (7 to $8 \mathrm{~d}$ ), whereas in the dairy studies progesterone increased gradually from basal to subluteal and finally to luteal concentrations during the first follicular wave (Rivera et al., 2011; Denicol et al., 2012). Influences of differences in progesterone profiles in cycling beef cows (increasing, decreasing, or constant) during dominant follicle growth on subsequent fertility have not been tested critically and warrant further study.

\section{Prebreeding Progesterone Milieu}

Recent reports indicated that fertility may be increased in timed AI programs when the duration of prebreeding progesterone exposure is shortened from 7 to $5 \mathrm{~d}$ and duration of proestrus is increased in beef cows (Mussard et al., 2007; Bridges et al., 2008) and dairy cows (Santos et al., 2010). When follicles were allowed to grow for 3 to $4 \mathrm{~d}$ in a luteal-phase progesterone milieu followed by $72 \mathrm{~h}$ of gonadotropin support (proestrus), P/AI was increased in beef (Bridges et al., 2008) and dairy cattle (Santos et al., 2010). Abbreviating further the duration of proestrus, however, adversely 
affected $\mathrm{P} / \mathrm{AI}$ even in cattle with larger ovulatory follicles (Bridges et al., 2010). In dairy cows, extending the period of follicle dominance did not alter fertilization risk, but reduced embryo quality, even when dominance of the ovulatory follicle was extended by $1.5 \mathrm{~d}$ (Cerri et al., 2009). Ovulations after a shortened proestrus were associated with shortened subsequent luteal phases and decreased blood progesterone concentrations in beef (Dadarwal et al., 2013) and dairy cattle (Peters and Pursley, 2003).

In general, in both genotypes, prolonged growth of follicles in a reduced progesterone milieu resulted in increased LH pulses, increased concentrations of estradiol, larger ovulatory follicle diameter, and subsequently decreased fertility (Wiltbank et al., 2011). Excessively small follicles also have been associated with reduced fertility. When smaller follicles are induced to ovulate in cattle, they produce less estradiol than normal spontaneously ovulated follicles (Vasconcelos et al., 2001). In beef cattle, ovulatory follicle size was not related to pregnancy outcome when follicles ovulated spontaneously after estrus, but ovulatory induction of small follicles resulted in subsequent decreased embryo survival between 27 and $60 \mathrm{~d}$ of gestation (Geary et al., 2013).

It is generally accepted that much of the variation in pregnancy risk at synchronized estrus or ovulation may be accounted for by the age of the dominant follicle, whether it became persistent or its growth phase occurred in the presence of elevated or reduced concentrations of progesterone (Inskeep, 2004; Santos et al., 2010; Wiltbank et al., 2011). Oocytes from persistent, and possibly aged, follicles are likely to be more advanced in their maturation than those of normal age and size (Revah and Butler, 1996; Mihm et al., 1999). These changes in premature maturation of the oocyte do not compromise fertilization risk, but resulting zygote development is retarded and early embryo death often occurs before the 16-cell stage (Inskeep, 2004).

Influence of presynchronization progesterone environment in beef cattle seems to differ from that of dairy cattle in its subsequent effect on timed AI pregnancy risk. Two experiments were conducted in suckled beef cattle with the objective of initiating the timed AI program in cows during proestrus or estrus [pre- $\mathrm{PGF}_{2 \alpha}$ treatment administered $3 \mathrm{~d}$ before the standard 7-d CO-Synch + controlled internal drug release (CIDR) insert timed AI program] or in diestrus (pre- $\mathrm{PGF}_{2 \alpha}$ at $10 \mathrm{~d}$ and pre-GnRH at $7 \mathrm{~d}$ before the timed AI program, respectively) and were compared with the standard 7-d CO-Synch + CIDR insert timed AI program (Hill et al., 2014). Timed AI P/AI did not differ in the former (55.5 vs. $52.2 \%$ ) or the latter (44.4 vs. $44.0 \%$ ) experiment compared with the control, respectively.
Part of the inability to manipulate the estrous cycle in beef cows compared with dairy cows is evident by the variable and often limited proportions of cows having established normal prebreeding estrous cycles. In the 2 beef cow experiments cited previously (Hill et al., 2014 ), $60.5 \%$ of 1,537 cows and $49.1 \%$ of 803 cows in the former and latter multiherd experiments, respectively, were estimated to be having normal estrous cycles before the onset of the TAI program. When progesterone concentrations at the onset of the CO-Synch + CIDR program from both experiments were combined, only primiparous, but not multiparous, cows benefitted from exposure to elevated concentrations of progesterone at the onset of the TAI program (Figure 1A). No such interaction, however, was detected between primiparous and multiparous dairy cows (Figure 1B). In dairy cattle, cows starting the Ovsynch timed AI program from d 5 through 12 of the cycle or in diestrus have improved P/AI at timed AI compared with cows starting Ovsynch at other stages of the cycle (Vasconcelos et al., 1999). Because of this discovery, multiple presynchronization programs consisting of $\mathrm{GnRH}$ and $\mathrm{PGF}_{2 \alpha}$ have been tested and found to improve P/AI of dairy cows submitted to a TAI program (see reviews by Bisinotto et al., 2014; Wiltbank and Pursley, 2014) compared with cows initiating a TAI program at random stages of the estrous cycle. The benefits in $\mathrm{P} / \mathrm{AI}$ in primiparous beef cows at greater concentrations of progesterone at the initiation of ovulation synchronization may simply reflect a greater proportion of prior established estrous cycles relative to their age-matched herd mates having lower concentrations of progesterone.

Combined data from 73 herd-year studies examined progesterone concentrations at 10 and $0 \mathrm{~d}$ before initiating estrus or ovulation synchronization studies in more than 8,500 suckled beef cows. Pregnancy outcomes in beef cows with low-progesterone status $(<1 \mathrm{ng} / \mathrm{mL})$ $10 \mathrm{~d}$ before the onset of the synchronization program benefitted from a greater concentration of progesterone $(>1 \mathrm{ng} / \mathrm{mL}) 10 \mathrm{~d}$ later at the onset of the synchronization period (Figure 2; Stevenson et al., 2015). In contrast, when progesterone status was high ( $\geq 4.0 \mathrm{ng} /$ $\mathrm{mL}) 10 \mathrm{~d}$ before the onset of the timed AI program (7-d CO-Synch + CIDR insert) and was elevated at CIDR insertion, pregnancy outcome was suppressed (Stevenson et al., 2015). Progestin supplementation (fed, ear implants, or intravaginal inserts) during a synchronization program increased blood progesterone concentration in suckled beef cows (Stevenson et al., $2003 \mathrm{~b}$ ), increased the proportion of cows detected in estrus (Stevenson et al., 2000; Larson et al., 2006), and increased P/AI (Lamb et al., 2001; Stevenson et al., 2003b); however, the increase in $\mathrm{P} / \mathrm{AI}$ from inclusion of 
the CIDR insert was primarily detected in cows with decreasing or low endogenous progesterone secretion during treatment (Echternkamp and Thallman, 2011; Lamb et al., 2001).
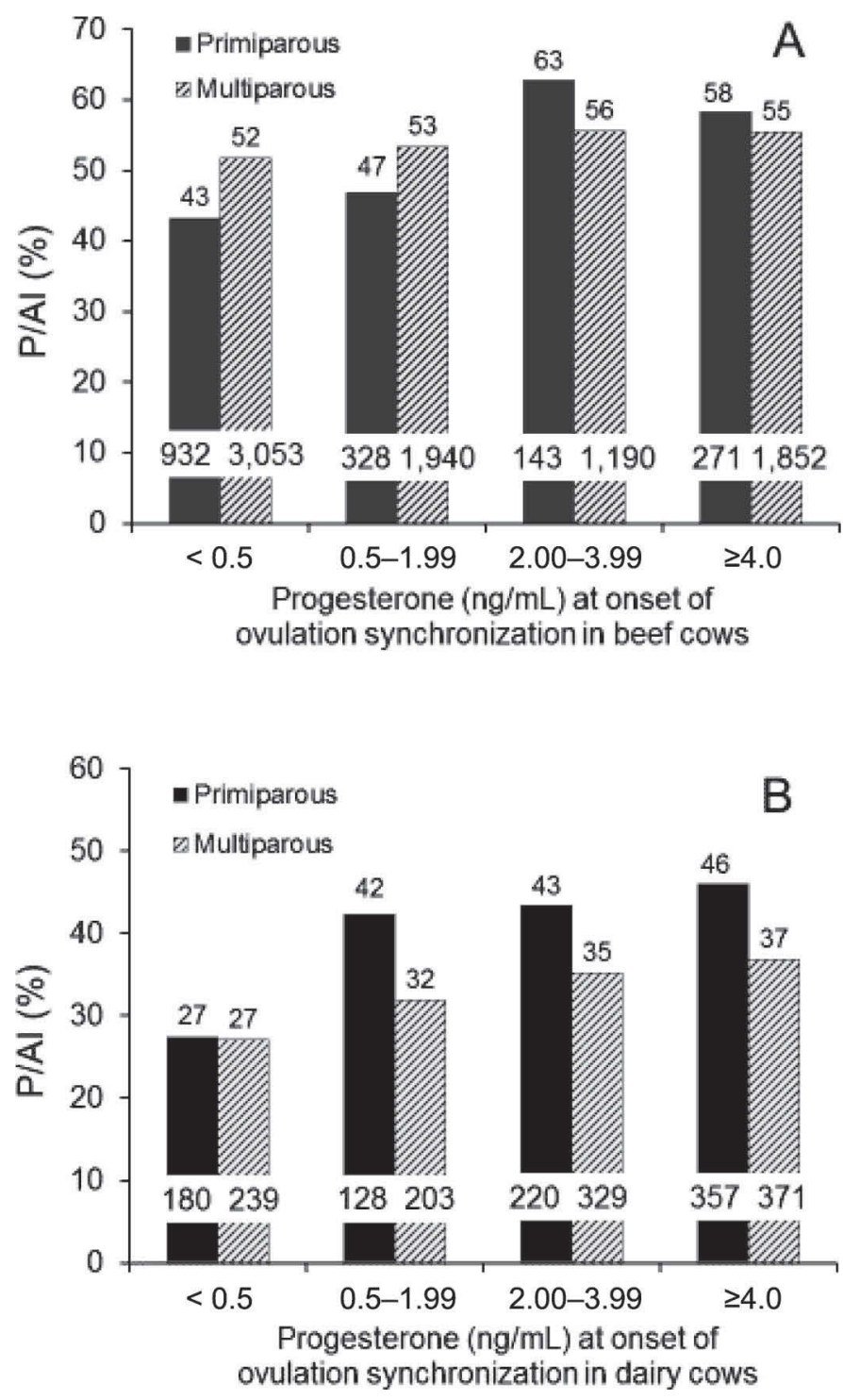

Figure 1. Pregnancy per AI $(\mathrm{P} / \mathrm{AI})$ of primiparous and multiparous beef (A; Stevenson et al., 2015) and dairy (B; Stevenson et al., 2008, 2012; Stevenson and Phatak, 2010; Stevenson, 2011, 2016; Pulley et al., 2013, 2015; Pulley and Stevenson, 2015) cows on the basis of progesterone concentration categories at the onset of the ovulation synchronization program (7-d CO-Synch + CIDR timed AI program: beef $=\mathrm{GnRH}$ injection and CIDR insertion, $7 \mathrm{~d}$ later $\mathrm{PGF}_{2 \alpha}$ and insert removal, 48 to $72 \mathrm{~h}$ later $\mathrm{GnRH}$ and $\mathrm{AI}$; dairy $=\mathrm{GnRH}$ injection, $7 \mathrm{~d}$ later $\mathrm{PGF}_{2 \alpha}, 48$ to $56 \mathrm{~h}$ later $\mathrm{GnRH}$ and $\left.\mathrm{AI}\right)$. An interaction of parity and progesterone category was detected $(P=0.011)$ such that $\mathrm{P} / \mathrm{AI}$ in primiparous, but not in multiparous, beef cows was greater when progesterone concentrations $>2 \mathrm{ng} / \mathrm{mL}$. In contrast, similar data for primiparous and multiparous dairy cows did not reveal an interaction $(P=0.784)$ between parity and progesterone category. Values within bars are the number of cows per bar.
Applying a progesterone insert or feeding orally active progestins as part of $\mathrm{AI}$ or timed AI programs in beef cattle improved subsequent $\mathrm{P} / \mathrm{AI}$ compared with controls (Patterson et al., 2003; Lamb et al., 2010). Prebreeding progestin treatment as part of the synchronization program delayed the onset of premature spontaneous estrus (Lamb et al., 2010), facilitated formation of a CL with normal functional life span in response to early weaning or gonadotropin treatments, particularly in anestrous cows (Inskeep, 2004), and specifically reduced post-AI short or asynchronous estrous cycles (Thompson et al., 1999; Inskeep, 2004) that normally follow first ovulation or first estrus in ruminants (Garverick and Smith, 1986). Likewise in dairy cattle, treatment of cows with an unknown CL status with 0,1 , or 2 progesterone inserts as part of an Ovsynch timed AI program did not alter subsequent $\mathrm{P} / \mathrm{AI}$, but cows with progesterone inserts had reduced premature luteolysis and fewer asynchronous post-AI estrous cycles than controls (Lima et al., 2009).

Furthermore, when dairy cows were targeted in either a 5- (Bisinotto et al., 2013) or 7-d (Stevenson et al., 2008; Bisinotto et al., 2015a) Ovsynch timed AI program, $\mathrm{P} / \mathrm{AI}$ was greater in non-CL cows treated with either 1 or 2 progesterone inserts compared with non-CL control cows, and P/AI of progesterone-treated non-CL cows was comparable with cows in diestrus

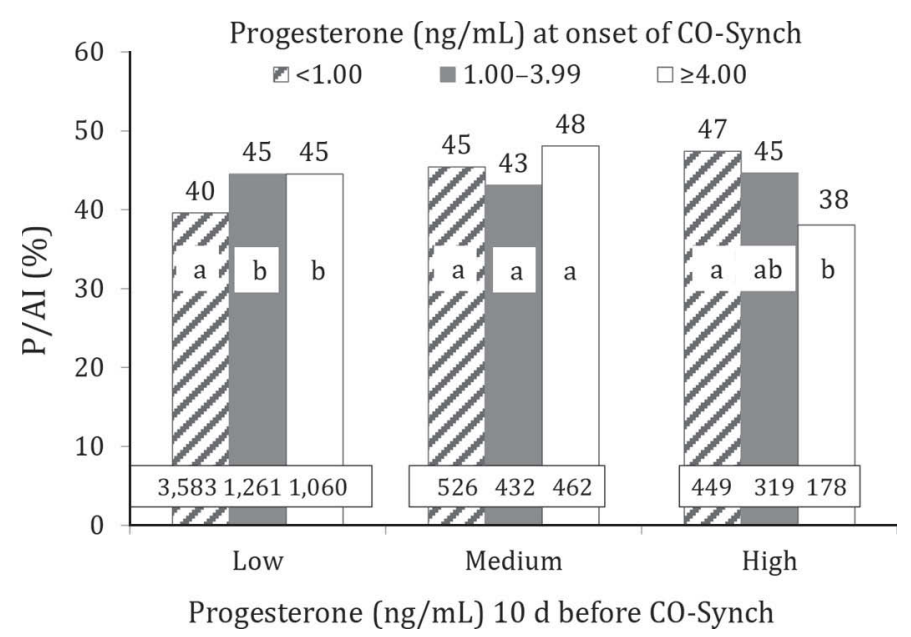

Figure 2. Three categories of progesterone concentrations (low, $<1.00$; medium, 1.00 to 3.99 ; and high, $\geq 4.00 \mathrm{ng} / \mathrm{mL}$ ) in blood serum in suckled beef cows $10 \mathrm{~d}$ before CO-Synch (categories on horizontal axis) and at onset of the CO-Synch (hatched, gray, and white bars) timed $\mathrm{AI}$ program (GnRH, $7 \mathrm{~d}$ later $\mathrm{PGF}_{2 \alpha}, 48$ to $72 \mathrm{~h}$ later $\mathrm{GnRH}$ and $\mathrm{AI}$ ) and resulting pregnancy per $\mathrm{AI}(\mathrm{P} / \mathrm{AI})$. A combination of both sample categories and resulting $\mathrm{P} / \mathrm{AI}$ illustrates their relationship to resulting $\mathrm{P} / \mathrm{AI}$. Means within progesterone concentration range $10 \mathrm{~d}$ before CO-Synch (i.e., low, medium, or high) without a common letter $(\mathrm{a}, \mathrm{b})$ differ $(P<0.05)$. Values within bars are the number of cows per bar. 
having a CL at the onset of the timed AI program. Therefore, targeting specific dairy cows with progesterone facilitated improved fertility. Progesterone status at the onset of synchronization was not critical to pregnancy outcome in multiparous beef cows, whereas $\mathrm{P} /$ AI was suppressed in primiparous beef cows starting in a low-progesterone environment (proestrus, metestrus, estrus, or anestrus; Stevenson et al., 2015). Because a large proportion of suckled beef cows are anestrous at the onset of the breeding season, incorporating a progestin as part of the synchronization program is nearly universally applied in the industry to facilitate improved fertility (Patterson et al., 2003; Lamb et al., 2010).

\section{GnRH-Induced LH Release and Ovulation}

Consistent with dairy cows (Giordano et al., 2012; Pulley et al., 2015), GnRH-induced LH release was suppressed at larger concentrations of progesterone in beef cows (Colazo et al., 2008; Perry and Perry, 2009) when timed AI programs were initiated with GnRH in the presence of a concurrently applied progesterone insert. In contrast, mean $\mathrm{LH}$ concentrations after $\mathrm{GnRH}$ did not differ on d 6 of the estrous cycle in lactating dairy cows treated simultaneously with a progesterone insert and either 100 or $200 \mu \mathrm{g}$ of $\mathrm{GnRH}$ compared with no insert and $100 \mu \mathrm{g}$ of $\mathrm{GnRH}$ (Mendonça et al., 2015). Although GnRH-induced LH release in beef heifers was greater (1) when exposed to reduced concentrations compared with elevated concentrations of progesterone, (2) in response to 200 than $100 \mu \mathrm{g}$ of GnRH regardless of progesterone concentration, and (3) in both progesterone environments when challenged with estradiol, neither GnRH nor estradiol significantly increased subsequent ovulation risk (Dias et al., 2010). In a similarly designed experiment in lactating dairy cows, GnRH-induced LH responses paralleled that observed in the previous study for both concentration of progesterone and dose of GnRH (Giordano et al., 2012). Too few dairy cows were enrolled in the latter dairy study to examine effects of progesterone on ovulation risk; however, in another dairy study (Giordano et al. 2013), increasing GnRH from 100 to $200 \mu \mathrm{g}$ at the onset of Ovsynch increased ovulation risk, but ovulation increased only in cows with lesser rather than greater concentrations of progesterone. A recent study (Pulley et al., 2015) consisting of more observations demonstrated reduced ovulation risk in dairy cows in response to $\mathrm{GnRH}$-induced LH release when progesterone averaged $4.5 \pm 0.2(56.4 \% ; 44 / 78)$ versus $0.2 \pm 0.1$ $\mathrm{ng} / \mathrm{mL}(83.3 \% ; 110 / 132)$.
In cycling beef cows, day of the estrous cycle at initiation of a timed AI program did not affect ovulatory follicle size or ovulatory response to $\mathrm{GnRH}$ before timed AI (Atkins et al., 2010). Furthermore, ovulatory response to the first GnRH injection of a timed AI program did not affect ovulatory response to the second GnRH injection in beef cattle (Atkins et al., 2010a), whereas the reverse was true in dairy cows (Vasconcelos et al., 1999).

\section{Progesterone Before $P G F_{2 \alpha}$ and at $A I$}

Reduced fertility also occurs when prebreeding progesterone was low during the estrous cycle preceding AI (Inskeep, 2004). In contrast, increased serum concentrations of progesterone during the estrous cycle before conception have been associated with increased conception risk in beef and dairy cattle (see Atkins et al., 2013). Progesterone concentrations were examined in 3,046 beef cows represented 73 herd-years (Stevenson et al., 2015) and in 2,026 dairy cows from 8 published studies consisting of 4 different herds of Holstein cows (Stevenson et al., 2008, 2012; Stevenson and Phatak, 2010; Stevenson, 2011, 2016; Pulley et al., 2013, 2015; Pulley and Stevenson, 2015). The pattern of proportions of cows within progesterone concentration ranges at the time of $\mathrm{PGF}_{2 \alpha}$ seemed to differ between genotypes (Figure 3A). Nearly $70 \%$ of beef cows had progesterone concentrations $<4 \mathrm{ng} / \mathrm{mL}$ at the time of $\mathrm{PGF}_{2 \alpha}$ compared with $44 \%$ of dairy cows, whereas only $30 \%$ of beef cows had progesterone $\geq 4 \mathrm{ng} / \mathrm{mL}$ compared with $56 \%$ of dairy cows (Figure 3A). A lesser proportion of beef cows at the lower progesterone concentration categories may be related to a greater proportion of anovulation in beef than dairy cows. Despite these proportional differences, subsequent $\mathrm{P} / \mathrm{AI}$ in beef cattle across the ranges of progesterone concentration did not differ, whereas in dairy cows $\mathrm{P} / \mathrm{AI}$ increased $(P<0.001)$ with increasing concentrations of progesterone at $\mathrm{PGF}_{2 \alpha}$ (Figure $3 \mathrm{~B}$ ). The greater pregnancy outcome in beef versus dairy cows may be related to the inclusion of a progesterone insert, which improves $\mathrm{P} / \mathrm{AI}$ in beef cattle relative to no insert (Lamb et al., 2001) and its additive effect on systemic progesterone concentrations in both anovulatory and cycling beef cows before $\mathrm{PGF}_{2 \alpha}$. Similar patterns in progesterone of dairy cows were reported (Santos et al., 2010) indicating that when progesterone was $\geq 1 \mathrm{ng} / \mathrm{mL}$ on the day of the $\mathrm{PGF}_{2 \alpha}$ of the timed AI protocol, P/AI was greater in those with $<1 \mathrm{ng} / \mathrm{mL}$ (36.5 vs. $17.5 \%)$.

Risk of luteolysis in our combined studies based on cut points of 0.5 or $1.0 \mathrm{ng} / \mathrm{mL} 66$ to $72 \mathrm{~h}$ after $\mathrm{PGF}_{2 \alpha}$ were 
86.2 and $96.6 \%$ in beef cattle, and at $48 \mathrm{~h}$ after $\mathrm{PGF}_{2 \alpha}$ were 69.7 and $89.1 \%$ in dairy cattle, respectively. Furthermore, although concentrations of progesterone at $\mathrm{PGF}_{2 \alpha} 66$ to $72 \mathrm{~h}$ before AI were greater $(P<0.01)$ in beef cows that failed to have luteolysis (cut point of 0.5 $\mathrm{ng} / \mathrm{mL})$ compared with beef cows with luteolysis $(6.1 \pm$ 0.2 vs. $4.6 \pm 0.1 \mathrm{ng} / \mathrm{mL})$, respectively, this relationship was not consistent $(P=0.317)$ when the cut point was $1.0 \mathrm{ng} / \mathrm{mL}(5.3 \pm 0.4$ vs. $4.9 \pm 0.1 \mathrm{ng} / \mathrm{mL})$. Concentra-
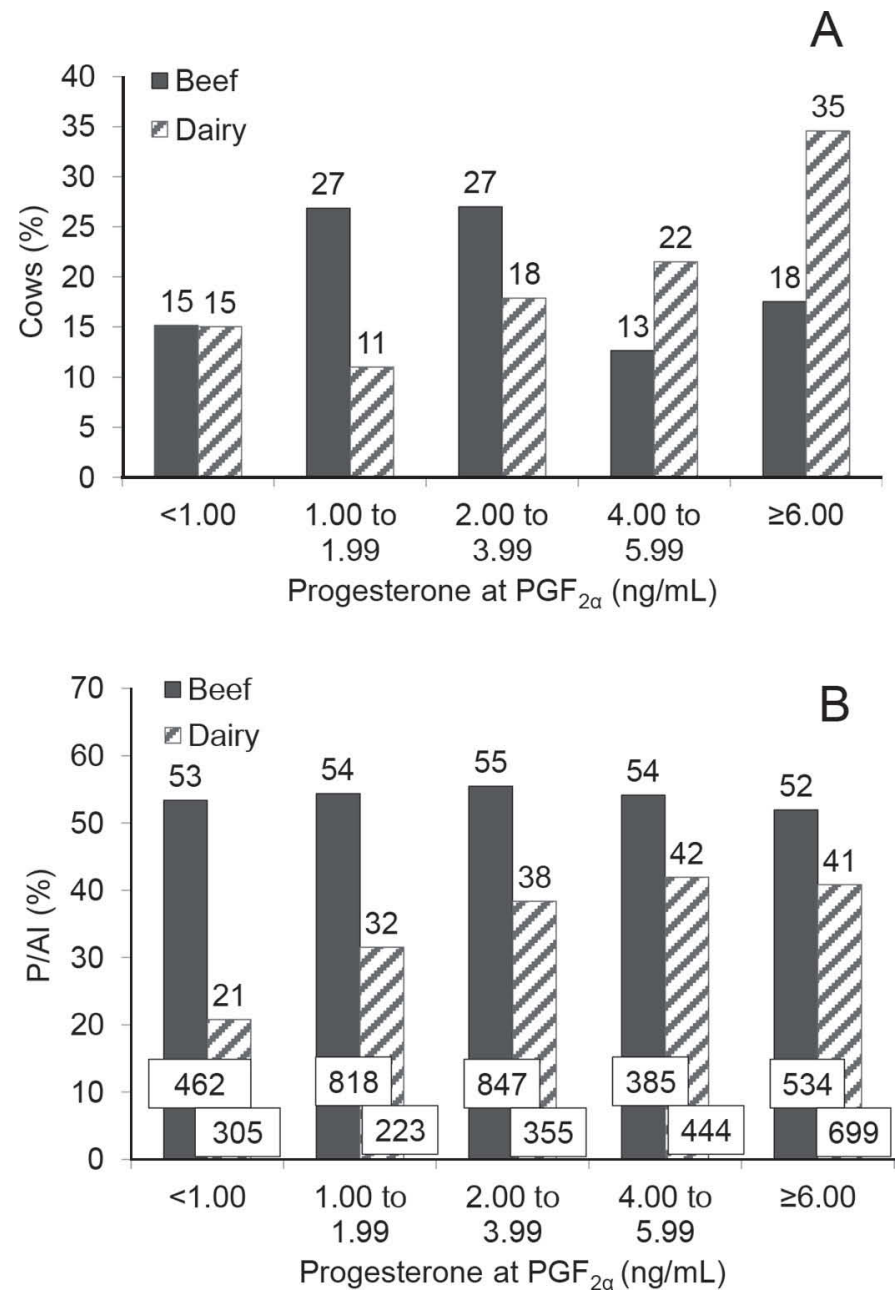

Figure 3. Progesterone concentrations in suckled beef and milked dairy cattle just before $\mathrm{PGF}_{2 \alpha}$ treatment (66 to $72 \mathrm{~h}$ before timed $\mathrm{AI}$ ). Panel A represents the percentages of cows within the illustrated concentration ranges; panel $\mathrm{B}$ illustrates subsequent $\mathrm{P} / \mathrm{AI}$ based on the progesterone concentration before $\mathrm{PGF}_{2 \alpha}$. Data for beef cows were adapted from 73 herd-years (Stevenson et al., 2015) and for dairy cattle from 8 studies (Stevenson et al., 2008, 2012; Stevenson and Phatak, 2010; Stevenson, 2011, 2016; Pulley et al., 2013, 2015; Pulley and Stevenson, 2015). Prebreeding progesterone concentration at the time of $\mathrm{PGF}_{2 \alpha}$ injection had no effect on $\mathrm{P} / \mathrm{AI}$ in beef cattle, whereas $\mathrm{P} / \mathrm{AI}$ increased $(P<0.001)$ with increasing concentration of progesterone from $<1.0$ to $4.0 \mathrm{ng} / \mathrm{mL}$ in dairy cows. Values within bars are the number of cows per bar.

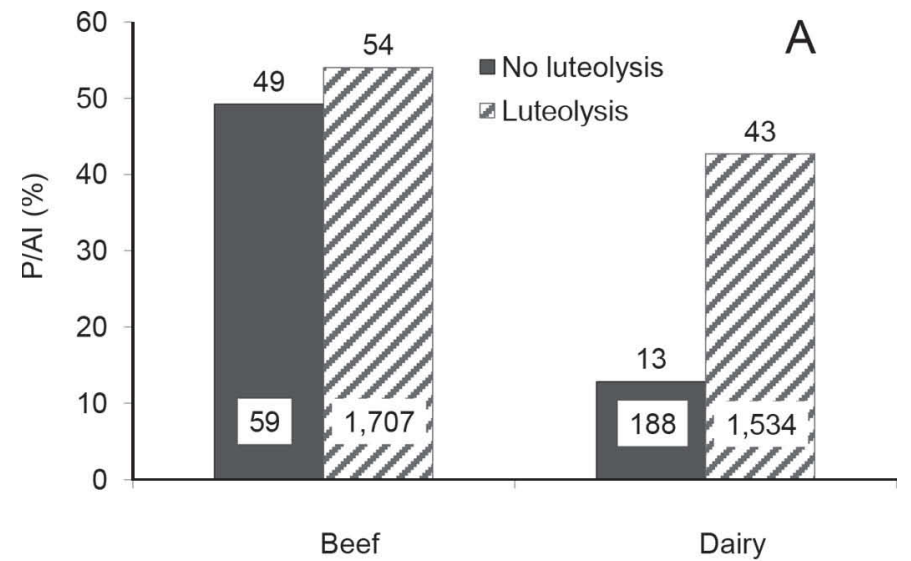

Luteolysis cut point for progesterone $<1.0 \mathrm{ng} / \mathrm{mL}$

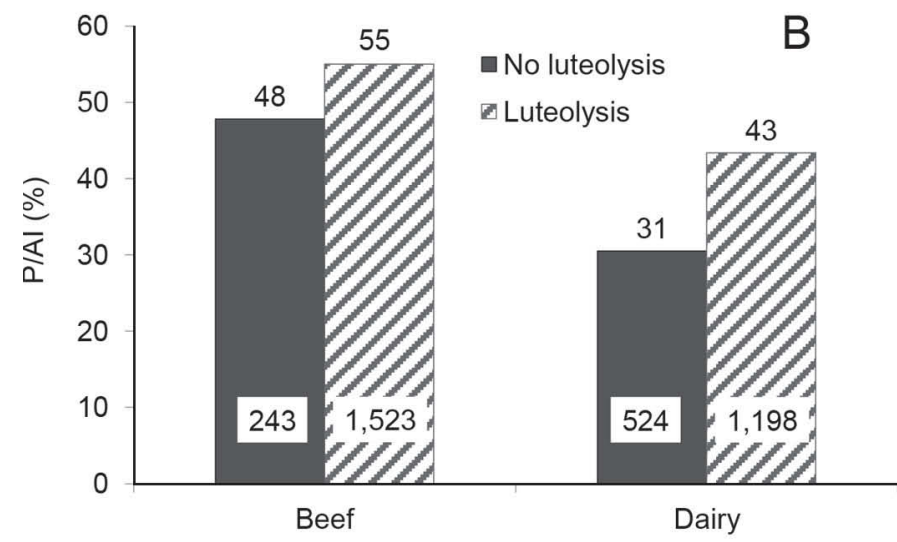

Luteolysis cut point for progesterone $<0.5 \mathrm{ng} / \mathrm{mL}$

Figure 4. Pregnancy per AI $(\mathrm{P} / \mathrm{AI})$ in beef and dairy cows on the basis of luteolysis at a cut point of 1.0 (A) or $0.5 \mathrm{ng} / \mathrm{mL}$ (B) at 48 to $72 \mathrm{~h}$ after $\mathrm{PGF}_{2 \alpha}$. Data for beef cows were adapted from 73 herd-years (Stevenson et al., 2015) and for dairy cattle from 8 studies (Stevenson et al., 2008, 2012; Stevenson and Phatak, 2010; Stevenson, 2011, 2016; Pulley et al., 2013, 2015; Pulley and Stevenson, 2015). At a cut point of $1.0 \mathrm{ng} / \mathrm{mL}, \mathrm{P} / \mathrm{AI}$ did not differ $(P=0.476)$ among beef cows with or without luteolysis, but $\mathrm{P} / \mathrm{AI}$ was greater $(P<0.001)$ for dairy cows with luteolysis than for dairy cows without luteolysis. At a cut point of $0.5 \mathrm{ng} / \mathrm{mL}, \mathrm{P} / \mathrm{AI}$ was greater $(P=0.044)$ for beef and dairy $(P<$ 0.001 ) cows with compared with respective genotypes without luteolysis. Values within bars are the number of cows per bar.

tions of progesterone in dairy cows followed a pattern consistent with beef cows with or without luteolysis at the $0.5-\mathrm{ng} / \mathrm{mL}$ cut point $(P<0.01 ; 5.9 \pm 0.1$ vs. $5.1 \pm$ $0.1 \mathrm{ng} / \mathrm{mL})$, but not at the $1.0-\mathrm{ng} / \mathrm{mL}$ cut point $(P=$ $0.916 ; 5.4 \pm 0.2$ vs. $5.4 \pm 0.1 \mathrm{ng} / \mathrm{mL})$, respectively. At a cut point of $1.0 \mathrm{ng} / \mathrm{mL}, \mathrm{P} / \mathrm{AI}$ did not differ $(P=0.476)$ among beef cows with or without luteolysis, but P/AI was greater $(P<0.001)$ for dairy cows with luteolysis than for dairy cows without luteolysis. At a cut point of $0.5 \mathrm{ng} / \mathrm{mL}, \mathrm{P} / \mathrm{AI}$ was greater $(P=0.044)$ for beef and dairy $(P<0.001)$ cows compared with their respective genotypes without luteolysis. (Figure 4A and 4B). 
The pattern of percentages of beef cows at varying progesterone concentrations at the time of AI seemed to differ, with more beef cows $(82.6 \%)$ concentrated in the lower ranges of progesterone concentration $(<0.41$ $\mathrm{ng} / \mathrm{mL}$ ) compared with $51.7 \%$ of dairy cows with similar progesterone concentrations at $48 \mathrm{~h}$ after $\mathrm{PGF}_{2 \alpha}$ (Figure 5A). Although concentrations of progesterone 66 to $72 \mathrm{~h}$ after $\mathrm{PGF}_{2 \alpha}$ at $\mathrm{AI}$ did not seem to affect $\mathrm{P} /$ $\mathrm{AI}$ in beef cattle, at concentrations $\leq 0.8 \mathrm{ng} / \mathrm{mL}$ at $\mathrm{AI}$ $\left(48 \mathrm{~h}\right.$ after $\left.\mathrm{PGF}_{2 \alpha}\right) \mathrm{P} / \mathrm{AI}$ was greater in dairy cattle compared with those having greater concentrations $>0.80 \mathrm{ng} / \mathrm{mL}$ (Figure 5B). From 2 other dairy studies, it was concluded that $\mathrm{P} / \mathrm{AI}$ was maximized when progesterone was $<0.24 \mathrm{ng} / \mathrm{mL}$ at timed AI (Santos et al., 2010) or when concentrations of progesterone 48 to $56 \mathrm{~h}$ after $\mathrm{PGF}_{2 \alpha}$ (16 to $24 \mathrm{~h}$ before timed $\mathrm{AI}$ ) were $<0.4 \mathrm{ng} / \mathrm{mL}$ (Wiltbank et al., 2014). Although AI is conducted at similar times (66 to $72 \mathrm{~h}$ ) after $\mathrm{PGF}_{2 \alpha}$ in both genotypes, timing of GnRH administration in the CO-synch + CIDR program in beef cows occurs at the time of AI when progesterone concentrations were more basal and differs from that of dairy cows when GnRH in the traditional Ovsynch program is administered at 48 to $56 \mathrm{~h}$ after $\mathrm{PGF}_{2 \alpha}$ before progesterone may be at basal concentrations. Because progesterone inhibits GnRH-induced LH release in both dairy (Giordano et al., 2012; Pulley et al., 2015) and beef cows (Colazo et al., 2008), the potential for greater ovulation risk at lower progesterone concentrations may facilitate greater synchrony of ovulation with semen placement in beef cows. A greater ovulation risk may explain the lack of decrease in $\mathrm{P} / \mathrm{AI}$ in beef cows observed in dairy cows. These differences in progesterone concentrations are consistent with the results in Figure 5A, in which much fewer beef than dairy cows have the more elevated concentrations at progesterone at 48 to $72 \mathrm{~h}$ after $\mathrm{PGF}_{2 \alpha}$.

A recent study (Gorzecka et al., 2011) endeavored to identify a complex of progesterone profile features associated with successful insemination in dairy cows including those profiles in the estrous cycle preceding AI, at estrus, and postestrus. Discriminant analysis failed to reveal clear differences, but they successfully identified $75 \%$ of the true pregnant cows and suggested that cows with shorter follicular phases before AI were associated with proper timing of postovulatory luteinization and greater likelihood in pregnancy.

\section{POSTOVULATORY LUTEAL FUNCTION}

Embryonic survival is a significant limiting factor to the success of pregnancy recognition, maintenance, and full-term delivery of a live calf. Some causes and mecha- nisms involved in embryo loss have been identified and much of the success seems to depend on circulating concentrations of progesterone at specific time points and changes in other hormones and functions that are a consequence of progesterone secretory patterns. Inskeep (2004) identified some critical time points in his review, including d 4 through 9 after estrus, d 14 through 17 during maternal recognition of pregnancy, and d 28 and 42 to 50 during the late embryonic, early fetal period.
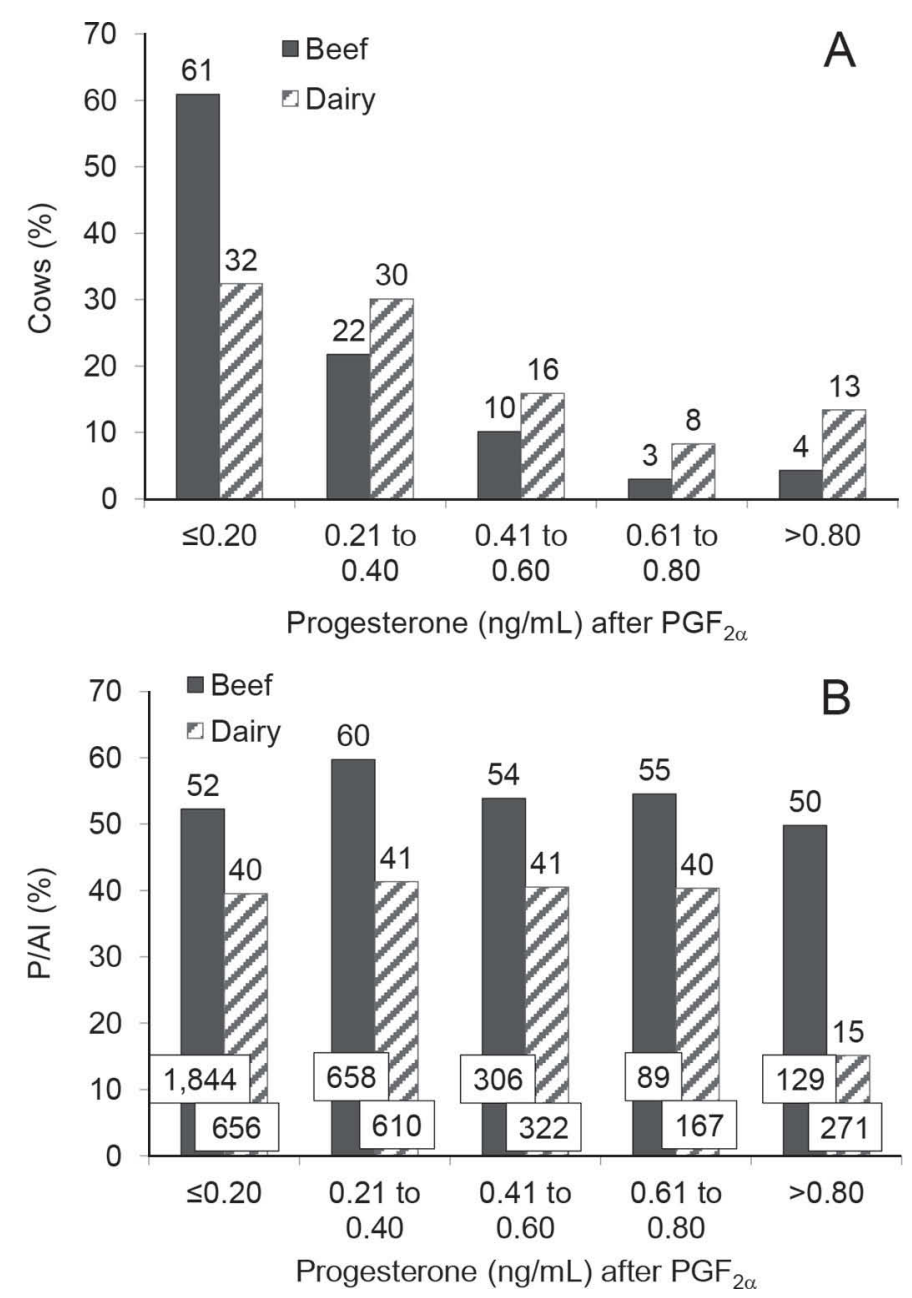

Figure 5. Panel A illustrates the percentage of suckled beef and milked dairy cows having progesterone concentrations within the illustrated ranges at 48 to $72 \mathrm{~h}$ after $\mathrm{PGF}_{2 \alpha}$ treatment (at timed $\mathrm{AI}$ ). Panel B illustrates subsequent P/AI based on the progesterone concentration at timed $\mathrm{AI}$ (66 to $72 \mathrm{~h}$ after $\mathrm{PGF}_{2 \alpha}$ ) for beef cows or 24 $\mathrm{h}$ before timed AI (48 $\mathrm{h}$ after $\mathrm{PGF}_{2 \alpha}$ ) for dairy cows. Data for beef cows were adapted from 73 herd-years (Stevenson et al., 2015) and for dairy cattle from 8 studies (Stevenson et al., 2008, 2012; Stevenson and Phatak, 2010; Stevenson, 2011, 2016; Pulley et al., 2013, 2015; Pulley and Stevenson, 2015). Concentration of progesterone did not seem to affect subsequent $\mathrm{P} / \mathrm{AI}$ in beef cattle, whereas $\mathrm{P} / \mathrm{AI}$ was reduced $(P<$ 0.01 ) at concentrations $>0.80 \mathrm{ng} / \mathrm{mL}$ at $\mathrm{AI}$ in dairy cattle compared to concentration categories $<0.80 \mathrm{ng} / \mathrm{mL}$. Values within bars are the number of cows per bar. 
Although pregnancy failure in livestock may result from either fertilization failure or pregnancy loss during gestation, fertilization failure seems to represent only a minor proportion of total pregnancy failure, except during summer in dairy cattle (Sartori et al., 2002). In an excellent review of losses associated with these critical time points, Santos et al. (2004) summarized the literature in beef and dairy cattle. Fertilization risk in lactating beef $(75 \%)$ and dairy cows (76\%) was similar, whereas it seems that fewer viable embryos were flushed from the uterus during the first week after AI in lactating dairy $(65.6 \%)$ than in suckled beef cows $(76.7 \%)$. In both cases, beef and dairy heifers had greater fertilization risk and more viable embryos than beef or dairy cows. Late embryonic and early fetal losses were quite similar for lactating beef and dairy cows, averaging approximately $10 \%$, and 2.5 to $4.2 \%$ in heifers, respectively (Santos et al., 2004).

Pregnancy loss in a recent summary of multiple studies in suckled beef cows (Stevenson et al., 2015) during the period between 35 and 60 to $70 \mathrm{~d}$ of gestation was $4.2 \%$ and was less in cows with BCS $>5$ depending on the independent variables included in the model. Pregnancy loss was neither affected by cycling nor progesterone status at the time of $\mathrm{PGF}_{2 \alpha}$ injection in beef cattle; this is in contrast to findings in lactating dairy cows, in which progesterone was inversely related to pregnancy loss and adversely affected in anovular cows (Wiltbank et al., 2014).

Communication between the conceptus and the endometrial epithelial cells leads to secretion of $\mathrm{PGF}_{2 \alpha}$ and resumption of ovulatory cycles with cessation of pregnancy (Santos et al., 2004). Progesterone secretion by the CL is essential for orchestrating the histotrophic environment for nourishment of the conceptus. The most important effect of progesterone in blocking luteolysis is to enhance conceptus development which, in turn, stimulates secretion of IFN- $\tau$ (Mann and Lamming, 2001). Furthermore, not only are progesterone concentrations important for pregnancy, but a delay in postovulatory rise in progesterone compromises conceptus development and its ability to secrete IFN- $\tau$, which results in reduced conception risk (Darwash and Lamming, 1998). Although no pre-established progesterone concentration determines a successful pregnancy (Mann and Lamming, 1999), progesterone concentrations on d 4 and 5 after mating in dairy cattle (but not later) were correlated with uterine luminal concentrations of IFN- $\tau$ on d 16 (Wathes et al., 2003). Because progesterone plays a major role in stimulating the production of several endometrial proteins and growth factors, supplemental progesterone during the first $4 \mathrm{~d}$ after AI in beef cattle increased morphological development and biosynthetic activity of d 14 conceptuses (Garrett et al., 1988). Furthermore, progesterone may have a direct effect on the embryo because progesterone receptors were found recently in bovine embryos (Clemente et al., 2009), although addition of progesterone to cultured embryos did not alter embryo quality (Fukui and Ono, 1989; Larson et al., 2011), embryo metabolism, or blastocyst cell numbers (Larson et al., 2011). Mann and Lamming (1999) demonstrated that supplemental progesterone was beneficial to fertility by increasing conception risk when administered before d 6 after AI, but not later than d 6 after AI in cows. Moreover, path analyses resulting from embryo transfers in beef cattle identified that the greatest influences on recovery of a live embryo on d 7 after induced ovulation and AI were increased serum concentration of progesterone on $\mathrm{d} 7$ and at the time of $\mathrm{PGF}_{2 \alpha}$ (Geary et al., 2013). Collectively, these data indicate that progesterone availability during early diestrus may benefit conception risk and embryonic survival.

Reduced conception risk and shorter luteal phases after AI observed in dairy cows inseminated during interluteal intervals greater than $8 \mathrm{~d}$ as measured by milk progesterone led Lamming and Darwash (1998) to conclude that a delayed rise in progesterone after ovulation might account for the compromised fertility. In contrast, the pattern of progesterone on $\mathrm{d} 4$ through 7 after mating did not compromise conception in beef cows (Pritchard et al., 1994); however, beef cows carrying unfertilized or degenerate embryos had reduced concentrations of progesterone on d 3 and 6 after AI compared with females with normally developing embryos (Maurer and Echternkamp, 1982).

\section{Enhancing Progesterone Postinsemination}

Progesterone concentration at embryo transfer (d 7 after estrus) or at $\mathrm{PGF}_{2 \alpha} 2 \mathrm{~d}$ before estrus directly and indirectly advanced embryo stage of development in donor cows at embryo transfer (Atkins et al., 2013). Increasing progesterone in beef heifers via an intravaginal progesterone insert starting on d 3 after estrus until slaughter tended to increase the proportion of viable embryos on d 13 (58 vs. $43 \%$ ) and 16 (90 vs. 50\%) and significantly increased embryonic length on d 13 and 16 (Carter et al., 2008). In a follow-up study (Carter et al., 2010), a progesterone insert applied on d 3 until embryo recovery significantly elevated progesterone concentrations from d 3.5 through 6 , whereas progesterone supplementation did not alter the proportion of embryos developing to the blastocyst stage in vivo, but those authors documented subtle changes to the embryo transcriptome that may be associated with ad- 
vance posthatching elongation. Enhanced progesterone concentrations in recipient beef heifers [human chorionic gonadotropin (hCG) treatment on d 2 or progesterone insert on d 3 through 5 after estrus] was capable of rescuing small embryos (blastocysts with smaller numbers of cells at transfer) compared with larger blastocysts and enhancing conceptus length by nearly 2 to 5 fold (O'Hara et al., 2014). Although inadequate systemic progesterone is one of the factors contributing to embryo losses occurring during the first $3 \mathrm{wk}$ after fertilization, infusion of progesterone during the first week after conception resulted in increased uterine glucose, decreased oviduct sulfate, and, to a lesser degree, oviduct sodium, but had no effect on any of the ions in the uterus (Hugentobler et al., 2010).

One recent study examined embryo loss between d 7 and 16 in beef heifers and parous nonlactating dairy cows (Berg et al., 2010). Although recipient losses were $6 \%$ in beef heifers compared with $16 \%$ in parous dairy cows, embryos retrieved from heifers were twice the size (indicating faster embryonic development or trophoblast proliferation in heifers) as those carried by parous dairy cow. Unfortunately, progesterone concentrations were not assessed.

Applying progesterone to cows after AI with the objective of resynchronizing the repeat estrus in nonpregnant cows and heifers increases rates of return to estrus, but generally reduced subsequent conception risk in beef cattle, although it enhanced fertility in dairy cows (see review by Lamb et al., 2010). Small doses of recombinant bST administered at $\mathrm{AI}$ and $14 \mathrm{~d}$ later resulted in only minor increases in progesterone, but enhanced fertility in dairy cows (Ribeiro et al., 2014) and had no effect in suckled beef cows (Mercadante et al., 2015).

Results from 10 published studies that used hCG treatment on d 4 through 9 post-AI in lactating dairy cows (Nascimento et al., 2013) indicated a significant increase in $\mathrm{P} / \mathrm{AI}$ of 3 percentage units in response to hCG treatment $[34 \%(752 / 2,213)$ vs. $37 \%(808 / 2,184)$, control vs. hCG treatment, respectively]. A prospective study was conducted in 6 commercial dairy herds in which Holstein cows $(\mathrm{n}=2,979)$ were treated with hCG $(2,000$ or $3,300 \mathrm{IU})$ or no further treatment on $\mathrm{d}$ 5 after timed AI. Pregnancies per AI were greater in cows treated with hCG $(40.8 \% ; 596 / 1,460)$ than control $(37.3 \% ; 566 / 1,519)$ cows. Concentrations of progesterone were increased resulting from hCG-induced ovulation of a secondary CL (Nascimento et al., 2013), enhanced volume of the original CL, or both (Stevenson et al., 2007).

Nearly $70 \%$ of beef cow recipients treated with hCG at the time of embryo transfer had ancillary CL at pregnancy diagnosis, greater progesterone concentrations, and greater pregnancy risk than controls (61.8 vs. 53.9\%; Wallace et al., 2011). Based on odds ratios, beef cow recipients receiving hCG, a fresh embryo, and having $\mathrm{BCS} \geq 5$ had the greatest pregnancy outcomes. Those authors concluded that increased progesterone resulting from hCG-induced ovulation reduced embryonic losses after transfer of embryos to recipients. In beef cows, concentrations of progesterone after timed AI were increased in pregnant cows after treatment with hCG, and hCG tended to increase pregnancy rates (56.3 vs. 50\%; Dahlen et al., 2010). Pregnant cows had greater concentrations of progesterone on d 7 after timed AI than cows that were not pregnant (Dahlen et al., 2010). Furthermore, treatment with hCG increased volume of luteal tissue on d 14 and concentrations of progesterone on d 14 and 33 after timed AI, and treatment with hCG tended to increase pregnancy rates at 5 of 6 locations from 1.1 to 27 percentage points (average $=10.2 \%$ ) compared with saline treatment (Dahlen et al., 2010). Taken together, because of its ability to induce ancillary CL and consistently increase concentrations of progesterone, hCG may increase pregnancy rates when administered to beef females $7 \mathrm{~d}$ after insemination or at embryo transfer. Because hCG-treated heifers having an accessory CL had greater pregnancy risk than those without an accessory CL (Chagas e Silva and Lopes da Costa, 2005), success of a protocol in beef females may depend on efficacy of hCG to induce an accessory CL rather than its effect on the original CL, which was demonstrated in hCG-treated dairy cows (Stevenson et al., 2007).

\section{CONCLUSIONS}

Although a preponderance of 2-follicular wave cycles have been detected in beef and dairy cows, a greater frequency of 2-wave cycles have been observed in beef than in dairy cows and fertility may be improved after 3 -wave cycles. In general, in both dairy and beef cattle, prolonged growth of follicles in a reduced progesterone milieu resulted in increased LH pulses, increased preovulatory follicle diameter, increased concentrations of estradiol, and a subsequently larger CL. In contrast, the progesterone milieu during follicular wave growth of the ovulatory follicle does not seem to affect subsequent pregnancy outcome in beef cows, whereas in dairy cows follicle development in an elevated progesterone environment increases $\mathrm{P} / \mathrm{AI}$ compared with a low progesterone milieu. A shortened proestrus reduced $\mathrm{P} / \mathrm{AI}$ in dairy and beef cattle, but in beef cattle $\mathrm{P} / \mathrm{AI}$ may be compensated by development of the preovulatory follicle in a low progesterone milieu. In timed AI 
programs, elevated concentrations of progesterone at $\mathrm{PGF}_{2 \alpha}$ and reduced concentrations at $\mathrm{AI}$ are critical to maximizing subsequent $\mathrm{P} / \mathrm{AI}$ in dairy cows, but may be less critical in beef cows. Because of its ability to induce multiple CL and consistently increase concentrations of progesterone, hCG may increase $\mathrm{P} / \mathrm{AI}$ when administered to beef females $7 \mathrm{~d}$ after insemination or at embryo transfer, and its success seems to depend on induction of ancillary CL, whereas in dairy cows increased fertility was detected in cows with ancillary CL and hCG-enhanced progesterone from original CL.

\section{REFERENCES}

Abreu, F. M., M. A. Coutinho da Silva, L. H. Cruppe, M. L. Mussard, B. R. Harstine, G. A. Bridges, T. W. Geary, and M. L. Day. 2014a. Impact of manipulation of progesterone concentrations during follicular development on ovulatory follicle growth and timed artificial insemination pregnancy rate in beef cows. J. Anim. Sci. 92(Suppl. 2):264. (Abstr.).

Abreu, F. M., M. L. Day, M. A. Coutinho da Silva, C. A. Madsen, T. Martins, L. H. Cruppe, B. R. Harstine, G. A. Bridges, and T. W. Geary. 2014b. Concentration of progesterone during early follicular development and pregnancy rate to AI in beef cows. J. Anim. Sci. 92(Suppl. 2):703. (Abstr.).

Ahmad, N., E. C. Townsend, R. A. Dailey, and E. K. Inskeep. 1997. Relationships of hormonal patterns and fertility to occurrence of two or three waves of ovarian follicles, before and after breeding, in beef cows and heifers. Anim. Reprod. Sci. 49:13-28.

Atkins, J. A., M. F. Smith, M. D. MacNeil, E. M. Jinks, F. M. Abreu, L. J. Alexander, and T. W. Geary. 2013. Pregnancy establishment and maintenance in cattle. J. Anim. Sci. 91:722-733.

Atkins, J. A., M. F. Smith, K. J. Wells, and T. W. Geary. 2010. Factors affecting preovulatory follicle diameter and ovulation rate after gonadotropin-releasing hormone in postpartum beef cows. Part I: Cycling cows. J. Anim. Sci. 88:2300-2310.

Austin, E. J., M. Mihm, M. P. Ryan, D. H. Williams, and J. F. Roche. 1999. Effect of duration of dominance of the ovulatory follicle on onset of estrus and fertility in heifers. J. Anim. Sci. 77:2219-2226.

Berg, D. K., J. van Leeuwen, S. Beaumont, M. Berg, and P. L. Pfeffer. 2010. Embryo loss in cattle between Days 7 and 16 of pregnancy. Theriogenology 73:250-260.

Bisinotto, R. S., L. O. Castro, M. B. Pansani, C. D. Narciso, N. Martinez, L. D. Sinedino, T. L. Pinto, N. S. Van de Burgwal, H. M. Bosman, R. S. Surjus, W. W. Thatcher, and J. E. Santos. 2015a. Progesterone supplementation to lactating dairy cows without a corpus luteum at initiation of the Ovsynch protocol. J. Dairy Sci. 98:2515-2528.

Bisinotto, R. S., R. C. Chebel, and J. E. Santos. 2010. Follicular wave of the ovulatory follicle and not cyclic status influences fertility of dairy cows. J. Dairy Sci. 93:3578-3587.

Bisinotto, R. S., I. J. Lean, W. W. Thatcher, and J. E. P. Santos. 2015b. Meta-analysis of progesterone supplementation during timed artificial insemination programs in dairy cows. J. Dairy Sci. 98:2472-2487.

Bisinotto, R. S., E. S. Ribeiro, F. S. Lima, N. Martinez, L. F. Greco, L. F. S. P. Barbosa, P. P. Bueno, L. F. S. Scagion, W. W. Thatcher, and J. E. P. Santos. 2013. Targeted progesterone supplementation improves fertility in lactating dairy cows without a corpus luteum at the initiation of the timed artificial insemination protocol. J. Dairy Sci. 96:2214-2225.

Bisinotto, R. S., E. S. Ribeiro, and J. E. P. Santos. 2014. Synchronisation of ovulation for management of reproduction in dairy cows. Animal 8:151-159.

Bleach, E. C. L., R. G. Glencross, and P. G. Knight. 2004. Association between ovarian follicle development and pregnancy rates in dairy cows undergoing spontaneous oestrous cycles. Reproduction 127:621-629.

Bridges, G. A., L. A. Helser, D. E. Grum, M. L. Mussard, C. L. Gasser, and M. L. Day. 2008. Decreasing the interval between GnRH and $\mathrm{PGF}_{2 \alpha}$ from 7 to 5 days and lengthening proestrus increases timedAI pregnancy rates in beef cows. Theriogenology 69:843-851.

Bridges, G. A., M. L. Mussard, C. R. Burke, and M. L. Day. 2010. Influence of the length of proestrus on fertility and endocrine function in female cattle. Anim. Reprod. Sci. 117:208-215.

Burke, J. M., J. H. Hampton, C. R. Staples, and W. W. Thatcher. 1998. Body condition influences maintenance of a persistent first wave dominant follicle in dairy cattle. Theriogenology 49:751-760.

Carter, F., N. Forde, P. Duffy, M. Wade, T. Fair, M. A. Crowe, A. C. O. Evans, D. A. Kenny, J. F. Roche, and P. Lonergan. 2008. Effect of increasing progesterone concentration from day 3 of pregnancy on subsequent embryo survival and development in beef heifers. Reprod. Fertil. Dev. 20:368-375.

Carter, F., F. Rings, S. Mamo, M. Holker, A. Kuzmany, U. Besenfelder, V. Havlicek, J. P. Mehta, D. Tesfaye, K. Schellander, and P. Lonergan. 2010. Effect of elevated circulating progesterone concentration on bovine blastocyst development and global transcriptome following endoscopic transfer of in vitro produced embryos to the bovine oviduct. Biol. Reprod. 83:707-719.

Cerri, R. L., R. C. Chebel, R. Rivera, C. D. Narciso, R. A. Oliveira, M. Amstalden, G. M. Baez-Sandoval, L. J. Oliveira, W. W. Thatcher, and J. E. P. Santos. 2011a. Concentration of progesterone during the development of the ovulatory follicle. II. Ovarian and uterine responses. J. Dairy Sci. 94:3352-3365.

Cerri, R. L., R. C. Chebel, R. Rivera, C. D. Narciso, R. A. Oliveira, W. W. Thatcher, and J. E. Santos. 2011b. Concentration of progesterone during the development of the ovulatory follicle: I. Ovarian and embryonic responses. J. Dairy Sci. 94:3342-3351.

Cerri, R. L. A., H. M. Rutigliano, R. C. Chebel, and J. E. P. Santos. 2009. Period of dominance of the ovulatory follicle influences embryo quality in lactating dairy cows. Reproduction 137:813-823.

Chagas e Silva, J., and L. Lopes da Costa. 2005. Luteotrophic influence of early bovine embryos and the relationship between plasma progesterone concentrations and embryo survival. Theriogenology 64:49-60.

Clemente, M., J. de La Fuente, T. Fair, A. Al Naib, A. Gutierrez-Adan, J. F. Roche, D. Rizos, and P. Lonergan. 2009. Progesterone and conceptus elongation in cattle: A direct effect on the embryo or an indirect effect via the endometrium? Reproduction 138:507-517.

Colazo, M. G., J. P. Kastelic, H. Davis, M. D. Rutledge, M. R. Martinez, J. A. Small, and R. J. Mapletoft. 2008. Effects of plasma progesterone concentrations on LH release and ovulation in beef cattle given GnRH. Domest. Anim. Endocrinol. 34:109-117.

Cooperative Regional Research Project. 1996. Relationship of fertility to patterns of ovarian follicular development and associated hormonal profiles in dairy cows and heifers. J. Anim. Sci. 74:19431952.

Crowe, M. A., M. G. Diskin, and E. J. Williams. 2014. Parturition to resumption of ovarian cyclicity: Comparative aspects of beef and dairy cows. Animal 8:40-53.

Dadarwal, D., R. J. Mapletoft, G. P. Adams, L. F. Pfeifer, C. Creelman, and J. Singh. 2013. Effect of progesterone concentration and duration of proestrus on fertility in beef cattle after fixed-time artificial insemination. Theriogenology 79:859-866.

Dahlen, C. R., S. L. Bird, C. A. Martel, K. Olson, J. S. Stevenson, and G. C. Lamb. 2010. Administration of human chorionic gonadotropin 7 days after fixed-time AI of suckled beef cows. J. Anim. Sci. $88: 2337-2345$.

Darwash, A. O., and G. E. Lamming. 1998. The importance of milk progesterone concentrations during early pregnancy in the cow. J. Anim. Breed. 2:41-43.

Denicol, A. C., G. Lopes Jr., L. G. Mendonca, R. A. Rivera, F. Guagnini, R. V. Perez, J. R. Lima, R. G. Bruno, J. E. Santos, and R. C. Chebel. 2012. Low progesterone concentration during the development of the first follicular wave reduces pregnancy per insemination of lactating dairy cows. J. Dairy Sci. 95:1794-1806. 
Dias, F. C. D., M. G. Colazo, J. P. Kastelic, R. J. Mapletoft, G. P. Adams, and J. Singh. 2010. Progesterone concentration, estradiol pretreatment, and dose of gonadotropin-releasing hormone affect gonadotropin-releasing hormone-mediated luteinizing hormone release in beef heifers. Domest. Anim. Endocrinol. 39:155-162.

Dias, F. C. F., R. J. Mapletoft, J. P. Kastelic, G. P. Adams, M. G. Colazo, B. C. Stover, O. Dochi, and J. Singh. 2012. Effect of length of progesterone exposure during ovulatory wave development on pregnancy rate. Theriogenology 77:437-444.

Diskin, M. G., D. R. Mackey, J. F. Roche, and J. M. Sreenan. 2003. Effects of nutrition and metabolic status on circulating hormones and ovarian follicle development in cattle. Anim. Reprod. Sci. $78: 345-370$.

Echternkamp, S. E., and R. M. Thallman. 2011. Factors affecting pregnancy rate to estrous synchronization and fixed-time artificial insemination in beef cattle. J. Anim. Sci. 89:3060-3068.

Fonseca, F. A., J. H. Britt, B. T. McDaniel, J. C. Wilk, and A. H. Rakes. 1983. Reproductive traits of Holsteins and Jerseys. Effects of age, milk yield, and clinical abnormalities on involution of cervix and uterus, ovulation, estrous cycles, detection of estrus, conception rate and days open. J. Dairy Sci. 66:1128-1147.

Fukui, Y., and H. Ono. 1989. Effects of sera, hormones and granulosa cells added to culture medium for in vitro maturation, fertilization, cleavage and development of bovine oocytes. J. Reprod. Fertil. $86: 501-506$.

Garrett, J. E., R. D. Geisert, M. T. Zavy, and G. L. Morgan. 1988. Evidence for maternal regulation of early conceptus growth and development in beef cattle. J. Reprod. Fertil. 84:437-446.

Garverick, H. A., and M. F. Smith. 1986. Mechanisms associated with subnormal luteal function. J. Anim. Sci. 62:92-105.

Geary, T. W., M. F. Smith, M. D. MacNeil, M. L. Day, G. A. Bridges, G. A. Perry, F. M. Abreu, J. A. Atkins, K. G. Pohler, E. M. Jinks, and C. A. Madsen. 2013. Influence of follicular characteristics at ovulation on early embryonic survival. J. Anim. Sci. 91:3014-3021.

Ginther, O. J., M. C. Wiltbank, P. M. Fricke, J. R. Gibbons, and K. Kot. 1996. Selection of the dominant follicle in cattle. Biol. Reprod. 55:1187-1194.

Giordano, J. O., P. M. Fricke, J. N. Guenther, G. Lopes Jr., M. M. Herlihy, A. B. Nascimento, and M. C. Wiltbank. 2012. Effect of progesterone on magnitude of the luteinizing hormone surge induced by two different doses of gonadotropin-releasing hormone in lactating dairy cows. J. Dairy Sci. 95:3781-3793.

Giordano, J. O., M. C. Wiltbank, P. M. Fricke, S. Bas, R. Pawlisch, J. N. Guenther, and A. B. Nascimento. 2013. Effect of increasing $\mathrm{GnRH}$ and $\mathrm{PGF}_{2 \alpha}$ dose during Double-Ovsynch on ovulatory response, luteal regression, and fertility of lactating dairy cows. Theriogenology 80:773-783.

Gorzecka, J., M. C. Codrea, N. C. Friggens, and H. Callesen. 2011. Progesterone profiles around the time of insemination do not show clear differences between pregnant and not pregnant dairy cows. Anim. Reprod. Sci. 123:14-22.

Hill, S. L., G. A. Perry, V. R. G. Mercadante, G. C. Lamb, J. R. Jaeger, K. C. Olson, and J. S. Stevenson. 2014. Altered progesterone concentrations by hormonal manipulations before a fixed-time artificial insemination CO-Synch + CIDR program in suckled beef cows. Theriogenology 82:104-113.

Hugentobler, S. A., J. M. Sreenan, P. G. Humpherson, H. J. Leese, M. G. Diskin, and D. G. Morris. 2010. Effects of changes in the concentration of systemic progesterone on ions, amino acids and energy substrates in cattle oviduct and uterine fluid and blood. Reprod. Fertil. Dev. 22:684-694.

Inskeep, E. K. 2004. Preovulatory, postovulatory, and postmaternal recognition effects of concentrations of progesterone on embryonic survival in the cow. J. Anim. Sci. 82(Suppl.):E24-E39.

Lamb, G. C., C. R. Dahlen, J. E. Larson, G. Marquezini, and J. S. Stevenson. 2010. Control of the estrous cycle to improve fertility for fixed-time artificial insemination in beef cattle: A review. J. Anim. Sci. 88:E181-E192.

Lamb, G. C., J. S. Stevenson, D. J. Kesler, H. A. Garverick, D. R. Brown, and B. E. Salfen. 2001. Inclusion of an intravaginal proges- terone insert plus GnRH and prostaglandin F2a for ovulation control in postpartum suckled beef cows. J. Anim. Sci. 79:2253-2259.

Lamming, G. E., and A. O. Darwash. 1998. The use of milk progesterone profiles to characterise components of subfertility in milked dairy cows. Anim. Reprod. Sci. 52:175-190.

Larson, J. E., R. L. Krisher, and G. C. Lamb. 2011. Effects of supplemental progesterone on the development, metabolism, and blastocyst cell number of bovine embryos produced in vitro. Reprod. Fertil. Dev. 23:311-318.

Larson, J. E., G. C. Lamb, J. S. Stevenson, S. K. Johnson, M. L. Day, T. W. Geary, D. J. Kesler, J. M. DeJarnette, F. N. Schrick, A. DiCostanzo, and J. D. Arseneau. 2006. Synchronization of estrus in suckled beef cows for detected estrus and artificial insemination and timed artificial insemination using gonadotropin-releasing hormone, prostaglandin $\mathrm{F}_{2 \mathrm{a}}$, and progesterone. J. Anim. Sci. $84: 332-342$

Lima, J. R., F. A. Rivera, C. D. Narciso, R. Oliveira, R. C. Chebel, and J. E. P. Santos. 2009. Effect of increasing amounts of supplemental progesterone in a timed artificial insemination protocol on fertility of lactating dairy cows. J. Dairy Sci. 92:5436-5446.

Lopez, H., L. D. Satter, and M. C. Wiltbank. 2004. Relationship between level of milk production and estrous behavior of lactating dairy cows. Anim. Reprod. Sci. 81:209-223.

Lucy, M. C., J. D. Savio, L. Badinga, R. L. De La Sota, and W. W. Thatcher. 1992. Factors that affect ovarian follicular dynamics in cattle. J. Anim. Sci. 70:3615-3626.

Mann, G. E., and G. E. Lamming. 1999. The influence of progesterone during early pregnancy in cattle. Reprod. Domest. Anim. 34:269-274.

Mann, G. E., and G. E. Lamming. 2001. Relationship between maternal endocrine environment, early embryo development and inhibition of the luteolytic mechanism in cows. Reproduction 121:175180 .

Masilo, B. S., J. S. Stevenson, R. R. Schalles, and J. E. Shirley. 1992 Influences of genotype and yield and composition of milk on interval to first postpartum ovulation in milked beef and dairy cows. J. Anim. Sci. 70:379-385.

Maurer, R. R., and S. E. Echternkamp. 1982. Hormonal asynchrony and embryonic development. Theriogenology 17:11-22.

Mendonça, L. G. D., M. Amstalden, and R. G. Chebel. 2015. Insertion of an intravaginal progesterone device at the time of gonadotropin-releasing hormone $(\mathrm{GnRH})$ injection affects neither GnRH-induced release of luteinizing hormone nor development of dominant follicle in early diestrus of lactating dairy cows. J. Dairy Sci. 98:3918-3925.

Mercadante, V. R. G., F. M. Ciriaco, D. D. Henry, P. L. P. Fontes, N. DiLorenzo, and G. C. Lamb. 2015. Effects of recombinant bovine somatotropin (bST) administration at breeding on the cow, conceptus and subsequent offspring performance of beef cattle. J. Anim. Sci. 93(Suppl. S3):534 (Abstr.).

Mihm, M., N. Curran, P. Hyttel, P. G. Knight, M. P. Boland, and J. F. Roche. 1999. Effect of dominant follicle persistence on follicular fluid oestradiol and inhibin and on oocyte maturation in beef heifers. J. Reprod. Fertil. 116:293-304.

Murphy, M. G., M. P. Boland, and J. F. Roche. 1990. Pattern of follicular growth and resumption of ovarian activity in post-partum beef suckler cows. J. Reprod. Fertil. 90:523-533.

Murphy, M. G., W. J. Enright, M. A. Crowe, K. McConnell, L. J. Spicer, M. P. Boland, and J. F. Roche. 1991. Effect of dietary intake on pattern of growth of dominant follicles during the oestrus cycle in beef heifers. J. Reprod. Fertil. 92:333-338.

Mussard, M. L., C. R. Burke, E. J. Behlke, C. L. Gasser, and M. L. Day. 2007. Influence of premature induction of a luteinizing hormone surge with gonadotropin-releasing hormone on ovulation, luteal function, and fertility in cattle. J. Anim. Sci. 85:937-943.

Nascimento, A. B., R. W. Bender, A. H. Souza, H. Ayres, R. R. Araujo, J. N. Guenther, R. Sartori, and M. C. Wiltbank. 2013. Effect of treatment with human chorionic gonadotropin on day 5 after timed artificial insemination on fertility of lactating dairy cows. J. Dairy Sci. 96:2873-2882. 
O'Hara, L., N. Forde, A. K. Kelly, and P. Lonergan. 2014. Effect of bovine blastocyst size at embryo transfer on day 7 on conceptus length on d 14: Can supplementary progesterone rescue small embryos? Theriogenology 81:1123-1128.

Patterson, D. J., F. N. Kojima, and M. F. Smith. 2003 A review of methods to synchronize estrus in replacement beef heifers and postpartum cows. J. Anim. Sci. 81(Suppl. 2):E166-E177.

Perry, G. A., and B. L. Perry. 2009. Effect of the timing of controlled internal drug-releasing device insertion on the gonadotropin-releasing hormone-induced luteinizing hormone surge and ovulatory response. J. Anim. Sci. 87:3983-3990.

Peters, M. W., and J. R. Pursley. 2003. Timing of final GnRH of the Ovsynch protocol affects ovulatory follicle size, subsequent luteal function, and fertility in dairy cows. Theriogenology 60:1197-1204.

Pritchard, J. Y., F. N. Schrick, and E. K. Inskeep. 1994. Relationship of pregnancy rate to peripheral concentrations of progesterone and estradiol in beef cows. Theriogenology 42:247-259.

Pulley, S. L., D. H. Keisler, and J. S. Stevenson. 2015. Concentrations of luteinizing hormone and ovulatory responses in dairy cows before timed artificial insemination. J. Dairy Sci. 98:6188-6201.

Pulley, S. L., and J. S. Stevenson. 2015. Five-day resynch programs in dairy cows including presynchronization and progesterone at two stages post-artificial insemination. J. Dairy Sci. 98:6243-6255.

Pulley, S. L., L. D. Wallace, H. I. Mellieon Jr., and J. S. Stevenson. 2013. Ovarian characteristics, serum concentrations, and fertility in lactating dairy cows in response to equine chorionic gonadotropin. Theriogenology 79:127-134.

Randel, R. D. 1990. Nutrition and postpartum rebreeding in cattle. J. Anim. Sci. 68:853-862.

Revah, I., and W. R. Butler. 1996. Prolonged dominance of follicles reduces the viability of bovine oocytes. J. Reprod. Fertil. 106:39-47.

Ribeiro, E. S., R. G. S. Bruno, A. M. Farias, J. A. Hernandez-Rivera, G. C. Gomes, R. Surjus, L. F. V. Becker, A. Birt, T. L. Ott, J. R. Branen, R. G. Sasser, D. H. Keisler, W. W. Thatcher, T. R. Bilby, and J. E. P. Santos. 2014. Low doses of bovine somatotropin enhance conceptus development and fertility in lactating dairy cows. Biol. Reprod. 90:1-12.

Rivera, F. A., L. G. Mendonça, G. Lopes Jr., J. E. Santos, R. V. Perez, M. Amstalden, A. Correa-Calderón, and R. C. Chebel. 2011. Reduced progesterone concentration during growth of the first follicular wave affects embryo quality but has no effect on embryo survival post transfer in lactating dairy cows. Reproduction 141:333-342.

Santos, J. E. P., C. D. Narciso, F. Rivera, W. W. Thatcher, and R. C. Chebel. 2010. Effect of reducing the period of follicle dominance in a timed AI protocol on reproduction in dairy cattle. J. Dairy Sci. 93:2976-2988.

Santos, J. E. P., W. W. Thatcher, R. C. Chebel, R. L. A. Cerri, and K. N. Galvão. 2004. The effect of embryonic death rates in cattle on the efficacy of estrus synchronization programs. Anim. Reprod. Sci. 82-83:513-535

Sartori, R., J. M. Haughian, R. D. Shaver, G. J. M. Rosa, and M. C. Wiltbank. 2004. Comparison of ovarian function and circulating steroids in estrous cycles of Holstein heifers and lactating cows. J. Dairy Sci. 87:905-920.

Sartori, R., R. Sartor-Bergfelt, S. A. Mertens, J. N. Guenther, J. J. Parrish, and M. C. Wiltbank. 2002. Fertilization and early embryonic development in heifers and lactating cows in summer and lactating and dry cows in winter. J. Dairy Sci. 85:2803-2812.

Stagg, K., L. J. Spicer, J. M. Sreenan, J. F. Roche, and M. G. Diskin. 1998. Effect of calf on follicular wave dynamics, gonadotropin and metabolic hormone changes, and interval to first ovulation in beef cows fed either of two energy levels postpartum. Biol. Reprod. 59:777-783.

Stevenson, J. S. 2011. Alternative programs to presynchronize estrous cycles in dairy cattle before a timed artificial insemination program. J. Dairy Sci. 94:205-217.

Stevenson, J. S. 2016. Ovarian characteristics and timed artificial insemination pregnancy risk after presynchronization with gonadotropin-releasing hormone 7 days before $\mathrm{PGF}_{2 \mathrm{a}}$ in dairy cows.
Theriogenology http://dx.doi.org/http://dx.doi.org/10.1016/j. theriogenology.2015.11.028.

Stevenson, J. S., S. L. Hill, G. A. Bridges, J. E. Larson, and G. C. Lamb. 2015. Progesterone status, parity, body condition, and days postpartum before estrus- or ovulation-synchronization in suckled beef cattle influences artificial insemination pregnancy outcomes. J. Anim. Sci. 93:2111-2123.

Stevenson, J. S., S. K. Johnson, and G. A. Milliken. 2003a. Incidence of postpartum anestrus in suckled beef cattle: Treatments to induce estrus, ovulation, and conception. Prof. Anim. Sci. 19:124-134

Stevenson, J. S., G. C. Lamb, D. J. Hoffman, and J. E. Minton. 1997. Review: Interrelationships of lactation and postpartum anovulation in suckled and milked cows. Livest. Prod. Sci. 50:57-74.

Stevenson, J. S., G. C. Lamb, S. K. Johnson, M. A. Medina-Britos, D M. Grieger, K. R. Harmoney, J. A. Cartmill, S. Z. El-Zarkouny, C. R. Dahlen, and T. J. Marple. 2003b. Supplemental norgestomet, progesterone, or melengestrol acetate increases pregnancy rates in suckled beef cows after timed inseminations. J. Anim. Sci. 81:571586.

Stevenson, J. S., and A. P. Phatak. 2010. Rates of luteolysis and pregnancy in dairy cows after treatment with cloprostenol or dinoprost. Theriogenology 73:1127-1138.

Stevenson, J. S., S. L. Pulley, and H. I. Mellieon Jr. 2012. Prostaglandin F $2 \alpha$ and gonadotropin-releasing hormone GnRH administration improve progesterone status, luteal number, and proportion of ovular and anovular dairy cows with corpora lutea before a timed AI program. J. Dairy Sci. 95:1831-1844.

Stevenson, J. S., D. E. Tenhouse, R. L. Krisher, G. C. Lamb, J. E. Larson, C. R. Dahlen, J. R. Pursley, N. M. Bello, P. M. Fricke, M. C. Wiltbank, D. J. Brusveen, M. Burkhart, R. S. Youngquist, and H. A. Garverick. 2008. Detection of anovulation by heatmount detectors and transrectal ultrasonography before treatment with progesterone in a timed insemination protocol. J. Dairy Sci. 91:2901-2915.

Stevenson, J. S., D. E. Tenhouse, M. A. Portaluppi, D. R. Eborn, S. Kacuba, and J. M. DeJarnette. 2007. Interventions after artificial insemination: Conception rates, pregnancy survival, and ovarian responses to gonadotropin-releasing hormone, human chorionic gonadotropin, and progesterone. J. Dairy Sci. 90:331-340.

Stevenson, J. S., K. E. Thompson, W. L. Forbes, G. C. Lamb, D. G. Grieger, and L. R. Corah. 2000. Synchronizing estrus and(or) ovulation in beef cows after combinations of $\mathrm{GnRH}$, norgestomet, and prostaglandin $\mathrm{F}_{2 \alpha}$ with or without timed insemination. J. Anim. Sci. 78:1747-1758.

Thompson, K. E., J. S. Stevenson, G. C. Lamb, D. M. Grieger, and C. A. Loest. 1999. Follicular, hormonal, and pregnancy responses of early postpartum suckled beef cows to GnRH, norgestomet, and prostaglandin $\mathrm{F}_{2 \alpha}$. J. Anim. Sci. 77:1823-1832.

Townson, D. H., P. C. W. Tsang, W. R. Butler, M. Frajblat, L. C. Griel Jr., C. J. Johnson, R. A. Milvae, G. M. Niksic, and J. L. Pate. 2002. Relationship of fertility to ovarian follicular waves before breeding in dairy cows. J. Anim. Sci. 80:1053-1058.

Vasconcelos, J. L. M., R. W. Silcox, G. J. Rosa, J. R. Pursley, and M. C. Wiltbank. 1999. Synchronization rate, size of the ovulatory follicle, and pregnancy rate after synchronization of ovulation beginning on different days of the estrous cycle in lactating dairy cows. Theriogenology 52:1067-1078.

Vasconcelos, J. L., R. Sartori, H. Olivera, J. Guenther, and M. Wiltbank. 2001. M. Reduction in size of the ovulatory follicle reduces subsequent luteal size and pregnancy rate. Theriogenology 56:307314

Walker, W. L., R. L. Nebel, and M. L. McGilliard. 1996. Time of ovulation relative to mounting activity in dairy cattle. J. Dairy Sci. 79:1555-1561.

Wallace, L. D., C. A. Breiner, R. A. Breiner, A. R. Spell, J. A. Carter, G. C. Lamb, and J. S. Stevenson. 2011. Administration of human chorionic gonadotropin at embryo transfer induced ovulation of a first wave dominant follicle, and increased progesterone and transfer pregnancy rates. Theriogenology 75:1506-1515. 
Wathes, D. C., V. J. Taylor, Z. Cheng, and G. E. Mann. 2003. Follicle growth, corpus luteum function and their effect on embryo development in postpartum dairy cows. Reprod. Suppl. 61:219-237.

Wehrman, M. E., M. S. Roberson, A. S. Crupp, F. N. Kojima, T. T. Stumpf, L. A. Werth, M. W. Wolfe, R. J. Kittok, and J. E. Kinder. 1993. Increasing exogenous progesterone during synchronization of estrus decreases endogenous 17 beta-estradiol and increases conception in cows. Biol. Reprod. 49:214-220.

White, F. J., R. P. Wettemann, M. L. Looper, T. M. Prado, and G. L. Morgan. 2002. Seasonal effects on estrous behavior and time of ovulation in nonlactating beef cows. J. Anim. Sci. 80:3053-3059.

Williams, G. L. 1990. Suckling as a regulator of postpartum rebreeding in cattle: A review. J. Anim. Sci. 68:831-852.

Wiltbank, M., H. Lopez, R. Sartori, S. Sangsritavong, and A. Gümen. 2006. Changes in reproductive physiology of lactating dairy cows due to elevated steroid metabolism. Theriogenology 65:17-29.

Wiltbank, M. C., and J. R. Pursley. 2014. The cow as an induced ovulatory: Timed AI after synchronization of ovulation. Theriogenology 81:170-185.
Wiltbank, M. C., R. Sartori, M. M. Herlihy, J. L. M. Vasconcelos, A B. Nascimento, A. H. Souza, H. Ayres, A. P. Cunha, A. Keskin, J. N. Guenther, and A. Gumen. 2011. Managing the dominant follicle in lactating dairy cows. Theriogenology 76:1568-1582.

Wiltbank, M. C., A. H. Souza, P. D. Carvalho, A. P. Cunha, J. O. Giordano, P. M. Fricke, G. M. Baez, and M. G. Diskin. 2014. Physiological and practical effects of progesterone on reproduction in dairy cattle. Animal 8:70-81.

Wolfenson, D., G. Inbar, Z. Roth, M. Kaim, A. Bloch, and R. BrawTal. 2004. Follicular dynamics and concentrations of steroids and gonadotropins in lactating cows and nulliparous heifers. Theriogenology 62:1042-1055.

Yavas, Y., and J. S. Walton. 2000. Postpartum acyclicity in suckled beef cows: A review. Theriogenology 54:25-55. 